kildehenvisninger: Hvem trækkes der mest på $\mathrm{i}$ analyserne? Underligt er det også, at et så vigtigt navn som Arnold Hauser end ikke omtales i fremstillingen eller er medtaget $i$ litteraturlisten, ligesom det kunne have været interessant - kærlighedsopfattelsens centrale placering taget $\mathrm{i}$ betragtning - at overvære en 'disput' mellem REL og historikeren Leo Tandrup. Men igen: Det er altsammen småindvendinger og piller ikke ved, at REL i det store hele har skrevet et både veldisponeret og læseværdigt kaleidoskopisk overblik over renæssancen og den moderne humanismes fremvækst, der formelig strutter af belæsthed og formidlingsglæde.

Apropos det sidste om den moderne humanisme: Det annonceres i indledningen, at bogen også rummer et sekundært, aktualiserende perspektiv, sådan som det netop fremgår af undertitlen. REL ønsker her at undgå såvel Jacob Burckhardts i dag klassiske idealiseringer (1860) af "opdagelsen af mennesket og verden", som Sløks dystopiske udsagn om, at "da mennesket tog magten, blev det afmægtigt" (1989). Der opteres her afslutningsvis og kort fortalt for en værdig individualisme hinsides egoismen og for en magt, der ikke ender i afmagt. Forsøget er ingenlunde nyt og forbliver nødvendigvis en løs skitse: Men selv om REL faktisk er mere loyal over for renæssancens eget univers end f.eks. Sløk, som han her med rette kritiserer for reduktionisme, så kommer der ikke argumenter på banen, der overbeviser nærværende anmelder om, at det i sidste ende er REL og ikke Sløk, der efterfølgende har fået ret. Afmagten som magtens vrangside kommer således, kunne man hævde, også til udtryk i værkets egen tilgang til humanismebegrebet: Værket 'magter' således fint at pege på individualiseringen og pluralismen som den overordnede, 'røde tråd' i den moderne arv fra renæssancen, men forbliver afmægtigt, når det $i d y$ bere forstand gælder om at vise hen til den angivelige kerne i humanismen: Menneskets værdighed og autentiske frihed.

Jens Viggo Nielsen

\section{Kloge Beslutninger}

Henrik Stampe Lund: Dommekraft. Et essay. Tiderne Skifter, 2006, 131 sider, kr. 198,-

Henrik Stampe Lund har skrevet en kort, klar og velskrevet lille bog, hvor han $i$ et forord, fem kapitler og en epilog diskuterer dømmekraftens betydning og rolle. Bogens overordnede konklusion er, at dømmekraften er en nødvendig, uundværlig og vigtig del af det sociale fællesskab. Manglende dømmekraft, hævder Lund, er en af de medvirkende årsager til sammenbrud i den sociale sfære, både helt konkret, som når dårligt gennemtænkte politiske beslutninger fører til lidelse og død for konkrete mennesker, og i mere abstrakt forstand, 
f.eks. i kraft af den manglende tilslutning til en politisk orden, som er det forudsigelige resultat af dårlige politiske beslutninger. Lund illustrerer denne pointe med talrige eksempler fra den virkelige verden, som både er med til at gøre læsningen interessant, og tjener til at understøtte Lunds overordnede tese om vigtigheden af en sund dømmekraft.

Der er således mange gode grunde til at læse Lunds bog - og da den er så kort, tager det ikke mere end et par timer, hvilket enhver vel bør kunne afsætte. Der er dog et par forhold ved bogen, som fremkalder panderynker, i det mindste hos en akademiker som undertegnede. For det første er det yderst sparsomt med henvisninger til de værker, Lund selv anvender i bogen. Nu ligger det selvfølgelig i selve essay-genren, at der ikke er tale om en akademisk afhandling, og at man derfor ikke kan stille de samme krav om fyldestgørende henvisninger som man f.eks. kan til en videnskabelig artikel. Givet essayets betydelige længde, og givet de undertiden meget direkte henvisninger (der citeres flere gange længere passager fra artikler og bøger), er det dog alligevel skuffende, at man ikke har forsynet bogen med en litteraturliste, hvor den anvendte litteratur blev præsenteret. Alternativt kunne Lund have præsenteret $i$ det mindste titlerne på de anvendte tekster nævnt i selve essayet, hvilket desværre heller ikke altid sker. For at tage et par eksempler: På side 66 bringes et citat af den franske filo- sof André Glucksmann, men man får intet at vide om, hvor der citeres fra. Og på side 122 omtales "en essaysamling, der handler om Europas kulturelle arv" skrevet af Hans-Georg Gadamer - men titlen på samlingen nævnes ikke.

Et andet problem med bogen er, at Lund konsekvent forbliver på anvendelses- eller handlingsniveauet; han fokuserer på konkrete eksempler, hvor dømmekraften faktisk er blevet udøvet og anvendt; nogle gange godt, andre gange dårligt. Det er ud fra disse eksempler, Lund udleder sine pointer om dømmekraftens betydning og menneskets fejlbarlighed. Som en modvægt til disse meget konkrete overvejelser ville det have været rart med en eller anden form for teoretisk overbygning eller perspektiv. Skønt Lund har meget at sige om, hvorledes dømmekraften udøves, og hvori god og dårlig dømmekraft består, så har han forbløffende lidt, for ikke at sige intet, at sige om, hvad dømmekraft egentlig er; og hvilken plads den har i et mere overordnet billede af menneskets handlingsliv. Det kan f.eks. undre, at man i en bog med titlen Dommekraft ikke har en eneste henvisning til Kant, der om nogen teoretiserede om dømmekraften. Og givet at Lund selv henviser til Gadamer, er det synd, at han ikke giver en mere udfoldet fremstilling af Gadamers begreb om dømmekraft. Det er prisværdigt, endog meget prisværdigt, at Lund ønsker at fremhæve dømmekraftens konkrete, praktiske 
betydning, men man kan spørge, om Lunds bog ikke ville have vundet ved også at inddrage et mere teoretisk perspektiv på dømmekraften.

Lunds bog kan med fordel læses af folk, som vil have et indtryk af dømmekraftens konkrete og virkelighedsnære karakter og faktiske betydning i menneskets handlingsliv. Ønsker man en introduktion til dømmekraftsbegrebet, der går ud over dette konkrete og anvendelsesorienterede sigte, går man derimod forgæves. Manglende tekstreferencer og manglende anvendelse af og henvisninger til de faktisk foreliggende teorier om dømmekraftsbegrebet gør det vanskeligt at anvende bogen som andet end inspirerende lystlæsning - men dertil er den også velegnet.

Carsten Fogh Nielsen

\section{Diskursen om diskursen}

David Howarth: Diskurs - En introduktion. Hans Reitzels Forlag, 2005, 232 sider, kr. 248,-

Hans Reitzels Forlag satser for tiden på samfundsteoretisk litteratur og har i den forbindelse udgivet Stig W. Jørgensens oversættelse af Davis Howarths bog Discourse fra 2000. Howarth er lektor i politisk teori ved University of Essex i England. Begrebet 'diskurs' har i en årrække været et varmt emne inden for de samfundsfaglige og humanistiske videnskaber, så det må være både økonomisk fornuftigt for forlaget og givtigt for den interesserede akademiker med en grundig introduktion til dette tema.

På bagsiden af oversættelsen beskrives bogen som "en kort, men dækkende introduktion til de forskellige teoretiske positioner inden for feltet." Ved nærmere øjesyn bliver det klart, at den kun indfrier den første forventning: Bogen er kort, men er ikke dækkende, da den bevidst fokuserer på samfundsvidenskabernes brug af diskursbegrebet og koncentrerer sig om den franske tradition for (post)strukturalisme og (post)marxisme. Howarth indrømmer da også, at hans sympati ligger hos Laclau \& Mouffe, hvis diskursteori ihærdigt forsvares og forfægtes.

Indledningsvis opremser Howarth en genealogi over diskursbegrebets forandringer (her forstået som diskursanalyse). I den første fase var diskursanalyse forbundet med talehandlingsteori og fokuserede på regler for dagligsproget (Austin \& Searle, Garfinkel). I den anden fase i 1960'erne og 1970'erne blev begrebet udvidet til at inkludere sociale praksisser inspireret af strukturalisme, hermeneutik og marxisme. I denne periode var hovedpersonen naturligvis Foucault. Diskursanalysens anvendelsesmuligheder eskalerede yderligere $\mathrm{i}$ den tredje fase, hvor diskurs kom til at indbefatte hele systemer af sociale relationer. Denne tredje fase benævnes diskursteori og er identisk med Laclau $\&$ Mouffes position.

Resten af bogen er en kompetent 